\title{
PENGENALAN OBJEK MUSEUM DAN MONUMEN PETA MENGGUNAKAN MARKERLESS AUGMENTED REALITY BERBASIS ANDROID
}

\author{
Yoga Hardi Firdaus ${ }^{* 1)}$, Jejen Jaenudin ${ }^{2)}$, Hersanto Fajri ${ }^{3)}$ \\ ${ }^{1}$ Fakultas Teknik \& Sains, Universitas Ibn Khaldun Bogor \\ email: yogahardi4@gmail.com \\ ${ }^{2}$ Fakultas Teknik \& Sains, Universitas Ibn Khaldun Bogor \\ email: zen@ft.uika-bogor.ac.id \\ ${ }^{3}$ Fakultas Teknik \& Sains, Universitas Ibn Khaldun Bogor \\ email: hersanto.fajri@gmail.com
}

\begin{abstract}
PETA Museum and Monument is a museum that collects various kinds of historical objects that are very important to the Indonesian people. To keep up with the times, there is an idea to apply Augmented Reality technology which is expected to make it easier for museums to introduce objects to the public. Augmented Reality is a technology that combines an artificial engineering object that has been made previously with the real world in real time. Artificial engineering objects can be in the form of 2-dimensional images or 3-dimensional images, but 2-dimensional images can only be seen from one direction, while 3-dimensional images can be seen from all directions, for example the front, left side, back, right side, up and down. There are several Augmented Reality methods for bringing up engineering objects, including using the marker method where the method requires a marker to bring up the object, but Augmented Reality has been developed to produce a new method that makes it easier for users, namely the Markerless method which is unnecessary again a marker for displaying engineering objects because the system has recognized various surrounding environmental surfaces such as recognizing object shapes, face shapes, plane shapes and so on. So that objects can be displayed in various places without the need for tools such as markers or boxshaped objects. Based on statcounter.com data, it is known that in 2020 the largest operating system in Indonesia is the Android operating system with a market share of $92.3 \%$ and is supported by data from statista.com which shows smartphone users in Indonesia are 81.87 million users. The use of Augmented Reality in the introduction of museum objects and map monuments is expected to assist museums in the introduction of using technology.
\end{abstract}

Keywords: museum object, augmented reality, markerless, marker, android

\section{PENDAhuluan}

Secara umum Museum adalah suatu lembaga tetap yang tidak mengutamakan pemerolehan keuntungan yang mengoleksi, mengonversi, meriset, mengomunikasikan benda sejarah pada masyarakat sebagai bahan pendidikan, serta rekreasi dan museum juga melayani kebutuhan publik dengan secara terbuka. Lebih lanjut menurut (Sutaarga, 1989), "Museum adalah sebuah lembaga permanen yang memberikan layanan untuk kepentingan masyarakat serta kemajuannya, tidak mencari keuntungan, terbuka untuk umum yang meneliti, memelihara, memamerkan, serta komunikasikan beberapa benda pembuktian material manusia didalam lingkungannya demi pendidikan, studi, dan rekreasi”.
Museum \& Monumen Pembela Tanah Air (PETA) yang berada dikota bogor adalah sebuah museum yang dibentuk oleh prakarsa Yayasan Pembela Tanah Air (YAPETA) yang bertujuan memberi penghargaan kepada mantan tentara PETA atas kontribusi serta perjuangan nya terhadap bangsa tercinta ini dan mengoleksi objek peninggalan sejarah para pembela tanah air seperti monumen yang berbentuk relief, tank baja, senapan, diorama, dan koleksi otentik berupa foto, senjata dan koleksi lainnya.

Hasil wawancara yang telah dilakukan penulis pada tanggal 8 Juni 2020 dengan Kapten CZI Suprihono (Kepala Museum dan Monumen PETA) terdapat beberapa informasi penting seperti diberikannya arahan oleh atasan agar museum menerapkan teknologi pengenalan digital yang diharapkan 
objek museum mengikuti perkembangan zaman sehingga lebih mudah di akses dan dapat tersebar luas dilingkungan masyarakat, namun hingga saat ini belum terlaksana dan belum adanya rencana untuk menerapkan teknologi sehingga permasalahan di museum ini adalah pengenalan objek tersebut masih menggunakan alat tradisional di mana membutuhkan banyak tenaga, usaha, waktu, energi dan materi.

Pengenalan secara digital yang sedang berkembang saat ini adalah Augmented Reality yaitu adalah teknologi yang menggabungkan dunia nyata dengan objek rekayasa yang telah dibuat sebelumnya bisa berupa gambar 2 dimensi atau pun gambar 3 dimensi, selain itu pengenalan menggunakan Augmented Reality sangat mudah dan tidak memakan biaya tambahan dalam pengoperasiannya, cukup dengan sebuah kamera smartphone yang memadai maka teknologi Augmented Reality bisa digunakan.

Augmented Reality tidak bisa dilihat dengan mata telanjang akan tetapi menggunakan alat yang memadai seperti misalnya kamera smartphone, webcam, kacamata pintar dan lain sebagainya. Alat yang sangat mudah di akses oleh pengguna untuk menggunakan Augmented Reality adalah kamera smartphone, karena menurut seorang peneliti yang bernama Andrew dari University of Oxford (Jurnal apps, 2018) mengatakan jika hasil penelitian terkait Smartphone bahwa dalam sehari Smartphone selalu digunakan selama 4 jam 17 menit atau jika diubah ke menit menjadi 257 menit. Dari durasi tersebut, diketahui bahwa para remaja tidak hanya mencari informasi dengan benda tersebut, akan tetapi menjalin atau melakukan interaksi sosial antar sesama pengguna dengan menggunakan Smartphone.

Berdasarkan diskusi penulis dengan Kapten CZI Suprihono maka penulis mencoba menerapkan Augmented Reality yang di mana lebih praktis dalam melakukan pengenalan objek Museum dan Monumen PETA secara teknologi digital. Pada zaman sekarang banyak orang lebih sering menggunakan Smartphone atau yang biasa disebut dengan telepon pintar untuk memenuhi kebutuhan sehari-hari karena benda tersebut lebih mudah dan praktis untuk dibawa kemana-mana. Pengenalan objek secara tradisional adalah hal biasa yang sudah digunakan pada umumnya, maka dari itu penulis menggunakan metode Augmented Reality agar masyarakat ataupun wisatawan dapat melihat dan mengetahui benda-benda peninggalan sejarah yang ada di Museum \& Monumen PETA kapan pun dan dimana pun.

\section{METODE PENELITIAN}

Metode penelitian yang akan digunakan adalah metode dengan siklus hidup pengembangan multimedia yang pertama kali dikenalkan oleh Luther (1994) lalu dikembangkan oleh Sutopo (2012), metode ini merupakan salah satu cara pendekatan penelitian dalam bidang desain grafis dan multimedia yang akan menerapkan suatu sistem atau sub sistem komputer seperti yang terlihat pada gambar 2.1

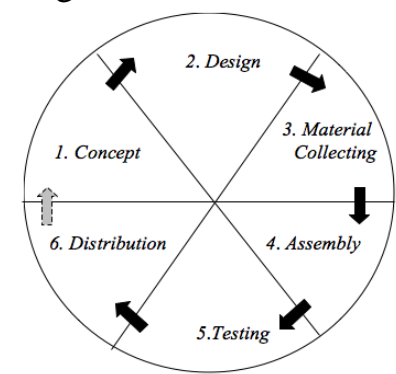

Gambar 3. 1 Metode Penelitian

Pengembangan Multimedia

\section{Concept}

Tahap awal dalam pengembangan sistem ini adalah mengadakan wawancara dengan pihak museum untuk mengetahui teknologi apa yang akan digunakan dalam pengenalan objek museum, lalu menentukan SDK (Source Development Kit) Markerless Augmented Reality yang cocok sehingga dapat digunakan orang banyak, selanjutnya membuat perencanaan dan tujuan dari multimedia yang akan dibuat serta sasaran audiens yang akan menggunakannya. Pada program ini dapat membantu memvisualisasikan objek Museum \& Monumen PETA dengan Markerless Augmented Reality.

\section{Design}

Jika pada tahap concept sudah selasai, maka tahap selanjutnya adalah tahap design (perancangan) tahap ini adalah tahap pembuatan spesifikasi material-material yang dibutuhkan dalam pembuatan sistem, seperti membuat rancangan antarmuka, membuat 
objek 3D museum, membuat dubbing museum, membuat asset-asset aplikasi dan menentukan spesifikasi minimal untuk menjalankan aplikasi. Sistem ini dirancang menggunakan flowchart dengan sistem rancangan struktur navigasi.

\section{Material Collecting}

Tahap ini mengumpulkan bahan-bahan yang akan digunakan dalam aplikasi seperti gambar objek museum, model animasi 3D objek museum dan suara dubbing terkait penjelasan objek museum.

\section{Assembly}

Jika pada tahap concept sudah selasai, maka tahap selanjutnya adalah tahap design (perancangan) tahap ini adalah tahap pembuatan spesifikasi material-material yang dibutuhkan dalam pembuatan sistem, seperti membuat rancangan antarmuka, membuat objek 3D museum, membuat dubbing museum, membuat asset-asset aplikasi dan menentukan spesifikasi minimal untuk menjalankan aplikasi. Sistem ini dirancang menggunakan flowchart dengan sistem rancangan struktur navigasi.

\section{Testing}

Uji coba sistem dilakukan melalui 2 (dua) tahap uji coba, yaitu :

a. Uji Coba Struktural

Uji coba struktural adalah uji coba yang dilakukan dengan cara membandingkan kesesuaian struktur atau alur program dengan rancangan sehingga bisa diketahui apakah sistem berjalan sesuai dengan rancangan atau tidak.

b. Uji Coba Fungsional

Uji coba fungsional adalah uji coba yang dilakukan dengan cara menguji setiap button, scroll, markerless augmented reality yang telah dibuat, apakah sudah berfungsi dengan baik sesuai rancangan atau belum, pada tahap uji ini akan mengetahui bug yang tertinggal dalam aplikasi tersebut.

\section{Distributing}

Tahap Distributing adalah tahap pengemasan aplikasi ke dalam bentuk format apk dan akan diserahkan kepada Museum \& Monumen PETA.

\section{HASIL DAN PEMBAHASAN}

1. Concept

Pertama kali penulis mengadakan wawancara terlebih dahulu dengan kepala dan pemandu museum untuk membahas teknologi apa yang akan digunakan untuk mengenalkan objek museum \& monumen peta secara digital. Dan hasil dari wawancara tersebut telah disepakati bahwa teknologi yang akan digunakan adalah markerless augmented reality. Selanjutnya penulis mencari sdk (source development kit) mana yang akan digunakan untuk membuat aplikasi pengenalan objek museum \& monumen peta menggunakan markerless augmented reality berbasis Android.

Pada tahap Concept (Konsep) menentukan sebuah tujuan dari multimedia serta Audiens yang menggunakannya. Program ini dirancang untuk membuat aplikasi pengenalan objek Museum \& Monumen PETA menggunakan markerless augmented reality berbasis Android dan Sasaran Audiens yang dituju adalah masyarakat umum atau pun para pengunjung wisatawan Museum \& Monumen PETA.

Perancangan awal, aplikasi ini terdiri dari tampilan awal (Splash Screen) yang menjelaskan sedikit tentang aplikasi, tampilan memuat (Loading Screen) yang akan memuat semua komponen yang ada didalam aplikasi, tampilan menu (Menu Screen) yang berisi beberapa tombol diantaranya adalah tombol galeri museum, tombol tentang museum, tombol bantuan, tombol profile, dan yang terakhir adalah tombol exit.

Pada tombol galeri museum akan berisi mengenai kumpulan objek-objek museum disertai dengan deskripsi objek serta augmented reality. Tombol tentang museum akan berisi informasi singkat tentang museum, visi museum, misi museum, serta kontak dan sosial media museum. Tersedia juga tombol bantuan yang berguna untuk memberikan tutorial cara menggunakan aplikasi hingga memunculkan augmented reality. Tombol profile berisi tentang ucapan terimakasih penulis kepada pihak yang terlibat, dan terakhir tombol exit dibuat untuk menghentikan seluruh kegiatan aplikasi.

Tabel 3. 1 Konsep

\begin{tabular}{|c|l|ll|}
\hline No & Konsep & Deskripsi & \\
\hline 1 & Judul & Pengenalan & Objek \\
\hline
\end{tabular}




\begin{tabular}{|c|c|c|}
\hline & & $\begin{array}{l}\text { Museum \& } \text { Monumen } \\
\text { PETA Menggunakan } \\
\text { Markerless Augmented } \\
\text { Reality berbasis Android. }\end{array}$ \\
\hline 2 & $\begin{array}{l}\text { Jenis } \\
\text { Multimedia }\end{array}$ & $\begin{array}{l}\text { Menggunakan } \\
\text { Markerless Augmented } \\
\text { Reality yang dikemas } \\
\text { menjadi } \\
\text { Android. }\end{array}$ \\
\hline 3 & Tujuan & $\begin{array}{l}\text { Tujuan konsep ini adalah } \\
\text { untuk mencoba } \\
\text { menerapkan Augmented } \\
\text { Reality Markerless dalam } \\
\text { metode pengenalan dan } \\
\text { pembelajaran sehingga } \\
\text { membantu } \\
\text { mempermudah, } \\
\text { menjelaskan dan } \\
\text { memvisualisasikan objek } \\
\text { Museum \& Monumen } \\
\text { PETA. }\end{array}$ \\
\hline 4 & Pengguna & $\begin{array}{l}\text { Pengguna aplikasi ini } \\
\text { adalah para pengunjung } \\
\text { Museum \& Monumen } \\
\text { PETA atau pun } \\
\text { masyarakat umum. }\end{array}$ \\
\hline 5 & Audio & $\begin{array}{l}\text { Berisi dubbing mengenai } \\
\text { objek museum dengan } \\
\text { format audio } *^{m p} 3 \text {. }\end{array}$ \\
\hline 6 & Gambar & $\begin{array}{lr}\text { Terdapat dua } & \text { gambar } \\
\text { yaitu gambar } 2 \mathrm{D} \text { dan } 3 \mathrm{D}, \\
\text { gambar 2D } & \text { berformat } \\
\text { *png untuk } r & \text { tampilan } \\
\text { splash screen , loading } \\
\text { screen, menu screen, dan } \\
\text { button. Adapun gambar } \\
\text { 3D berformat } & \text { *fbx } \\
\text { adalah } & \text { untuk } \\
\text { menampilkan } & \text { objem } \\
\text { Museum \& } & \text { Monumen } \\
\text { PETA ketika } & \text { menggunakan r } \\
\text { Augmented Reality. }\end{array}$ \\
\hline 7 & SDK & VOID AR \\
\hline
\end{tabular}

\section{Design}

Tahap design (perancangan) tahap ini adalah tahap pembuatan spesifikasi materialmaterial yang dibutuhkan dalam pembuatan sistem pengenalan objek Museum \& Monumen PETA. untuk merancang sistem maka menggunakan flowchart dan juga perancangan sistem secara detail menggunakan perancangan story board.

\section{a. User Interface Splash Screen}

Tampilan pertama ketika masuk ke dalam aplikasi dan tampilan ini menampilkan informasi singkat mengenai aplikasi.

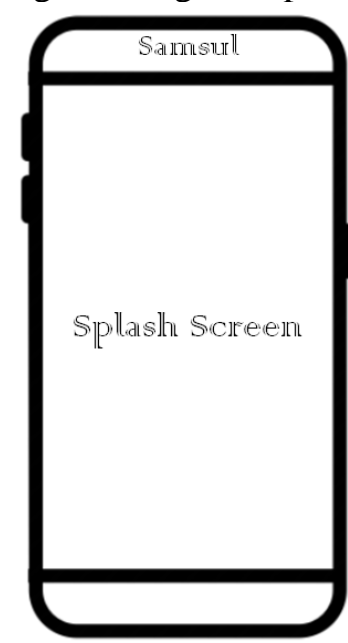

Gambar 3.1 User Interface Splash Screen

\section{b. User Interface Loading Screen}

Suatu tampilan yang berguna untuk menunggu ketika sistem sedang memuat seluruh komponen yang ada didalam aplikasi.

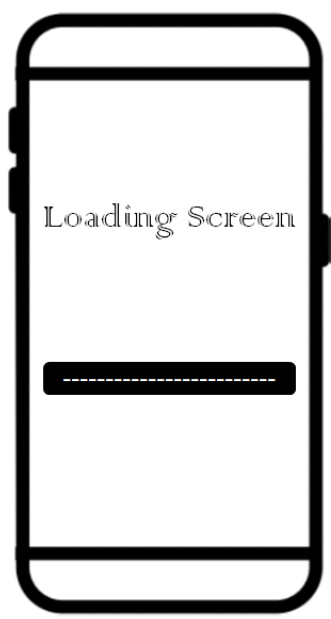

Gambar 3.2 User Interface Loading Screen

c. User Interface Menu Screen

Pada bagian ini berisi beberapa pilihan menu. 
Vol.3 No.2, Desember 2020

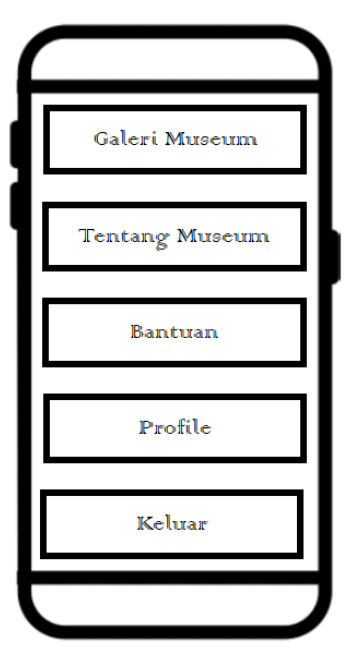

Gambar 3.3 User Interface Menu Screen

d. User Interface Galeri Museum

Bagian ini berisi objek museum \& monumen peta yang sudah dijadikan model animasi 3 dimensi dan dapat ditampilkan dengan menggunakan markerless augmented reality.

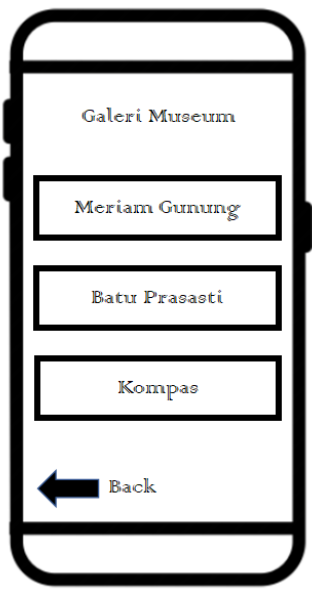

Gambar 3.4 User Interface Galeri Museum

e. User Interface Objek Museum

Berisi penjelasan singkat objek museum dan gambar 3 dimensi objek museum yang dapat ditampilkan dengan menggunakan markerless augmented reality serta diiringi pengisi suara untuk menjelaskan objek museum tersebut.

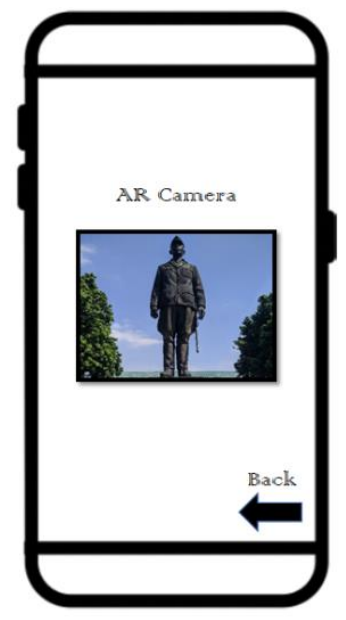

Gambar 3.5 User Interface Objek Museum

f. User Interface Kuis

Berisi pertanyaan dengan pilihan ganda terkait objek museum.

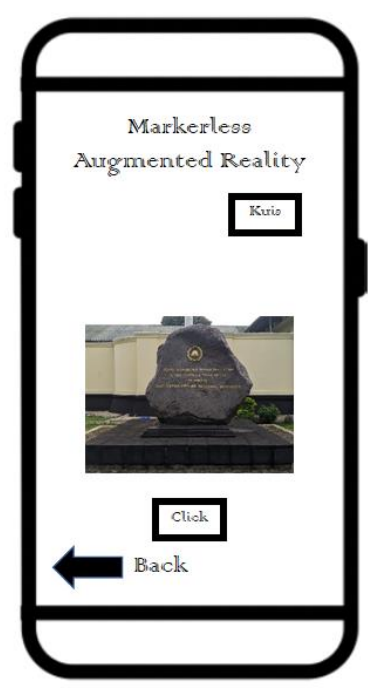

Gambar 3.6 User Interface Kuis

g. User Interface Tentang Museum

Berisi suatu tampilan informasi singkat mengenai museum \& monumen peta. 


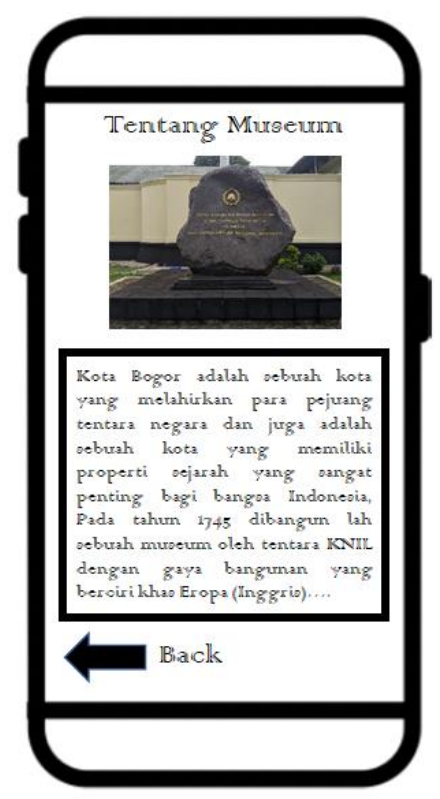

Gambar 3.7 User Interface Tentang Museum

h. User Interface Bantuan

Petunjuk mengenai bagaimana cara menggunakan aplikasi jika pengguna masih kebingungan dalam mengoperasikan aplikasi.

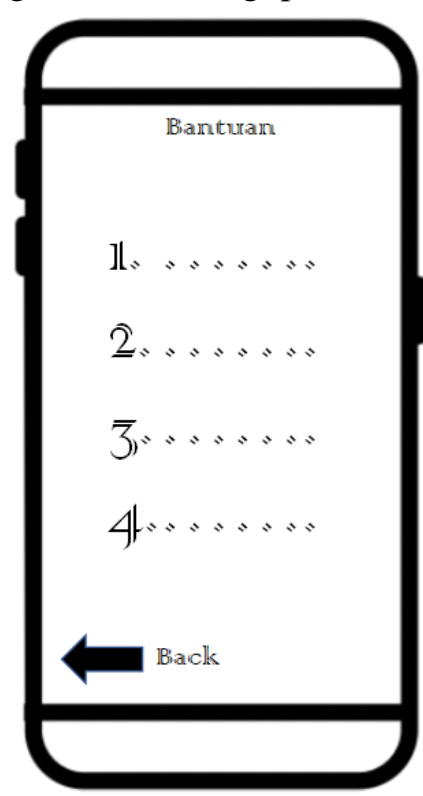

Gambar 3.8 User Interface Bantuan

i. User Interface Profil

Menampilkan ucapan terimakasih kepada pihak-pihak yang terlibat.

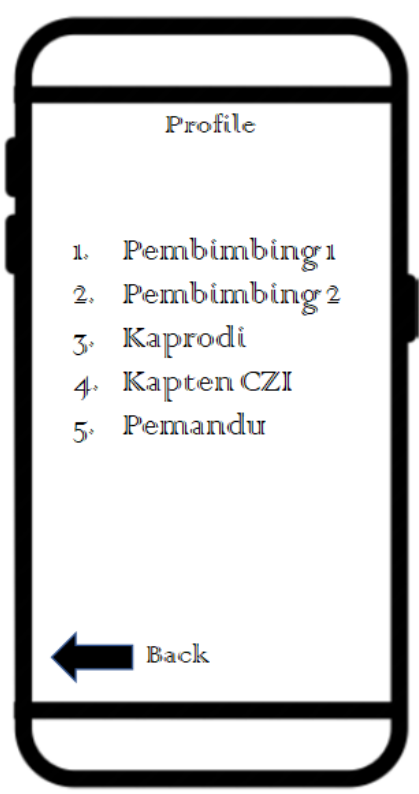

Gambar 3.9 User Interface Profil

\subsection{Struktur Navigasi}

Menggunakan model hierarki yang telah dimodifikasi secara menyeluruh. Pada Struktur navigasi menghasilkan diagram yang menghubungkan scene satu dengan scene lain nya.

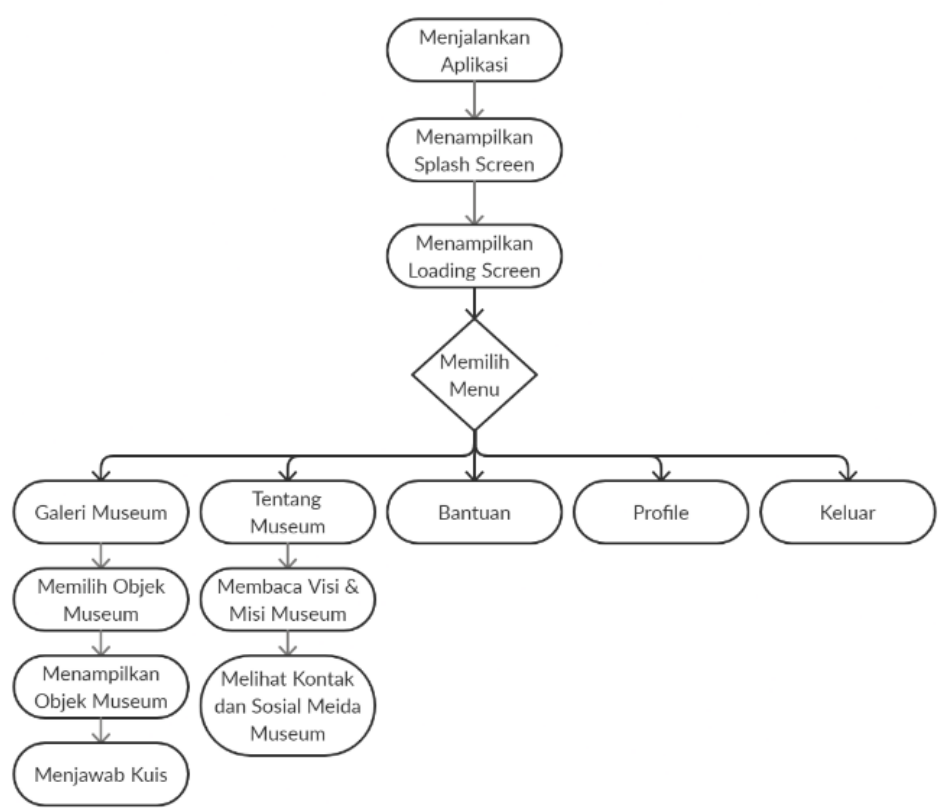

Gambar 3. 10 Struktur Navigasi

\subsection{Flowchart}

Pada tahap ini adalah membuat diagram alir sistem dengan simbol-simbol tertentu yang menggambarkan suatu proses sistem secara mendetail serta hubungan nya antara 
satu proses dengan proses lainnya dalam suatu program yang dibuat.

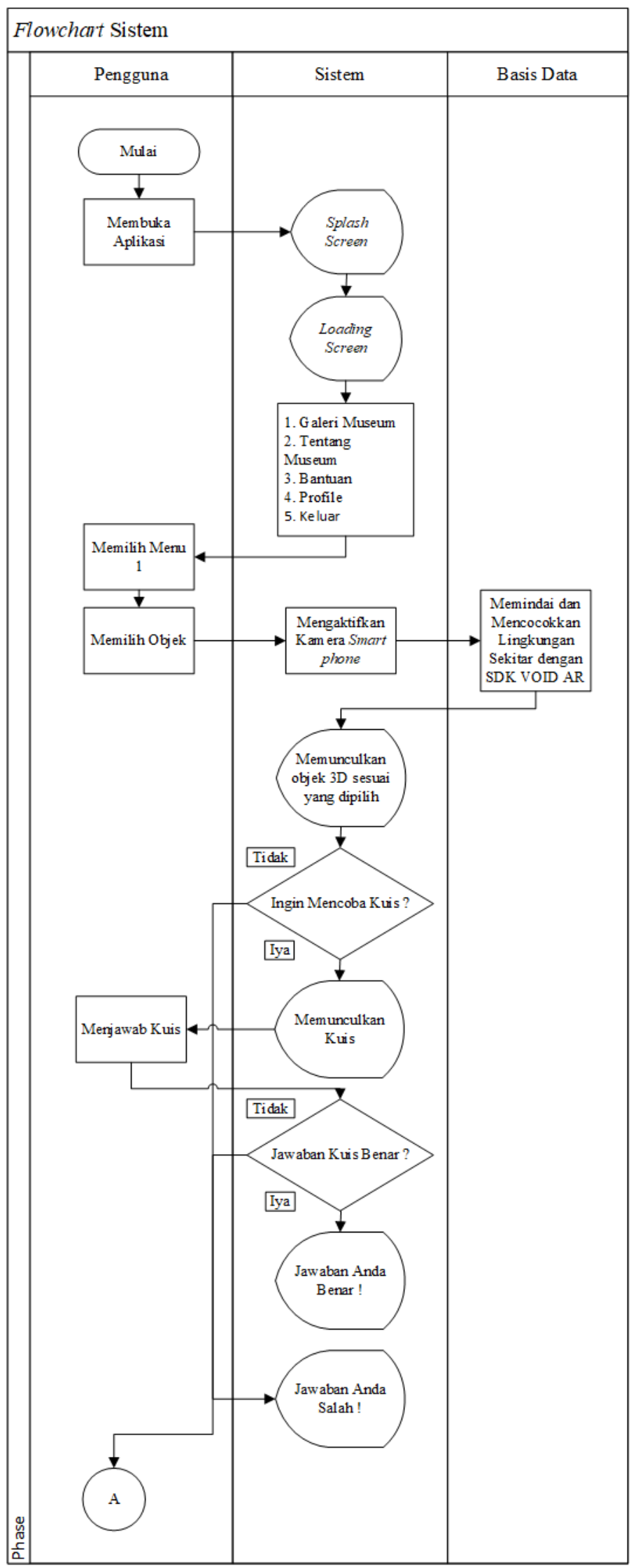

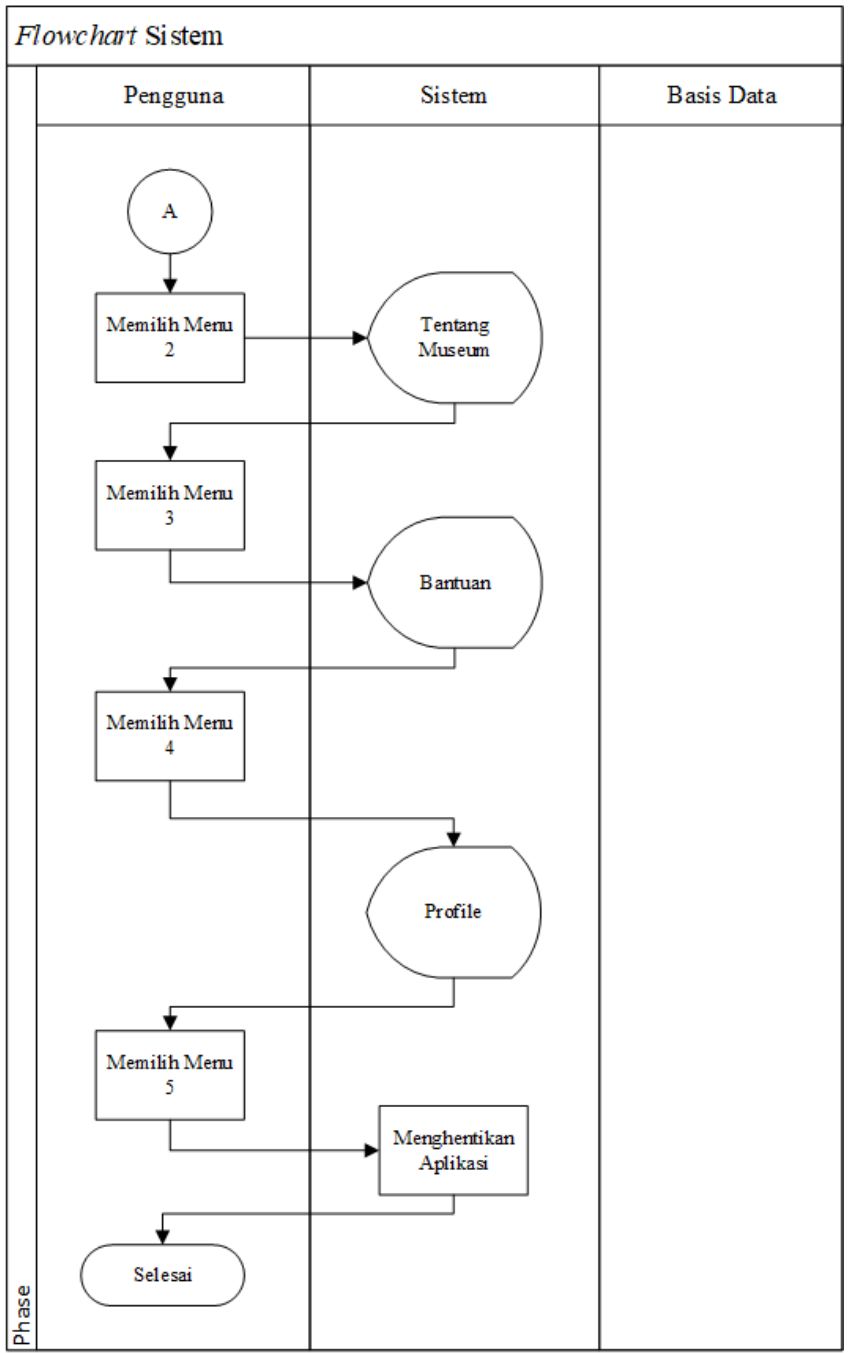

Gambar 3. 11 Flowchart Sistem

\subsection{Use Case Diagram}

Use Case Diagram adalah gambaran yang menjelaskan hubungan antara pengguna dengan aplikasi yang dibuat. Berikut ini adalah proses yang terdapat dalam aplikasi pengenalan objek museum dan monumen peta menggunakan markerless augmented reality berbasis android. 


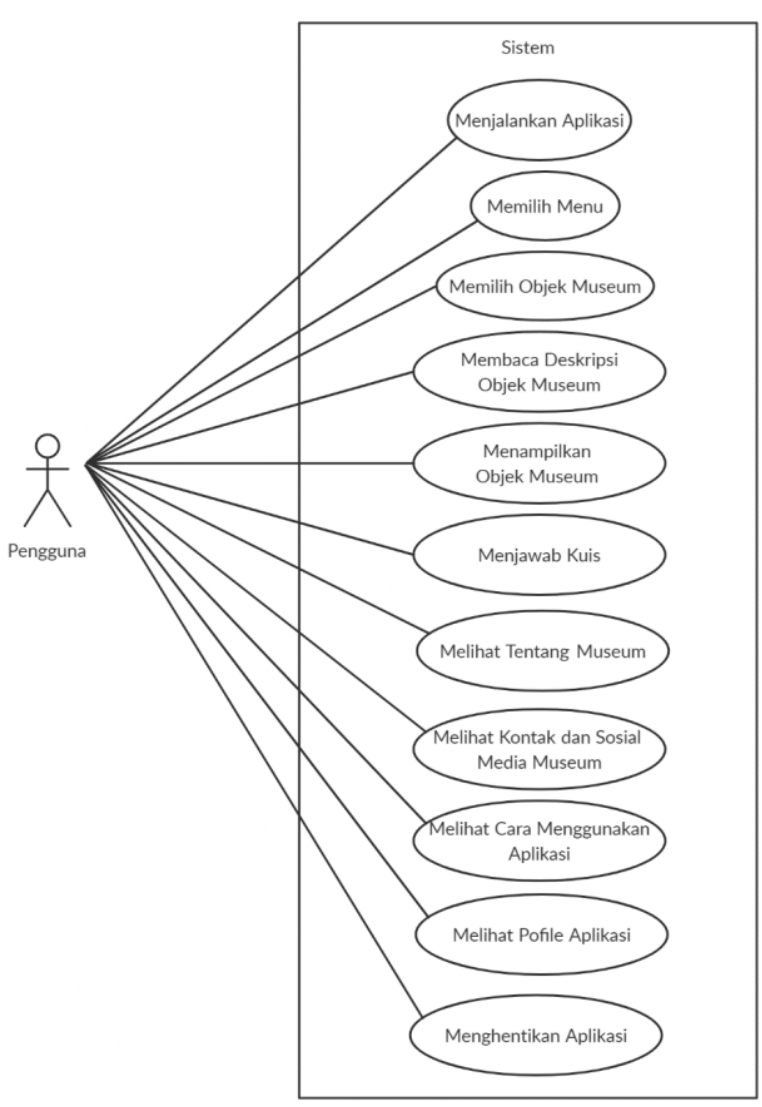

2.4 Deployment Diagram

Gambar 3. 12 Use Case Diagram

\subsection{Deployment Diagram}

adalah diagram yang menggambarkan hubungan antara perangkat lunak dengan perangkat keras serta format-format apa saja yang digunakan untuk membangun sistem tersebut.

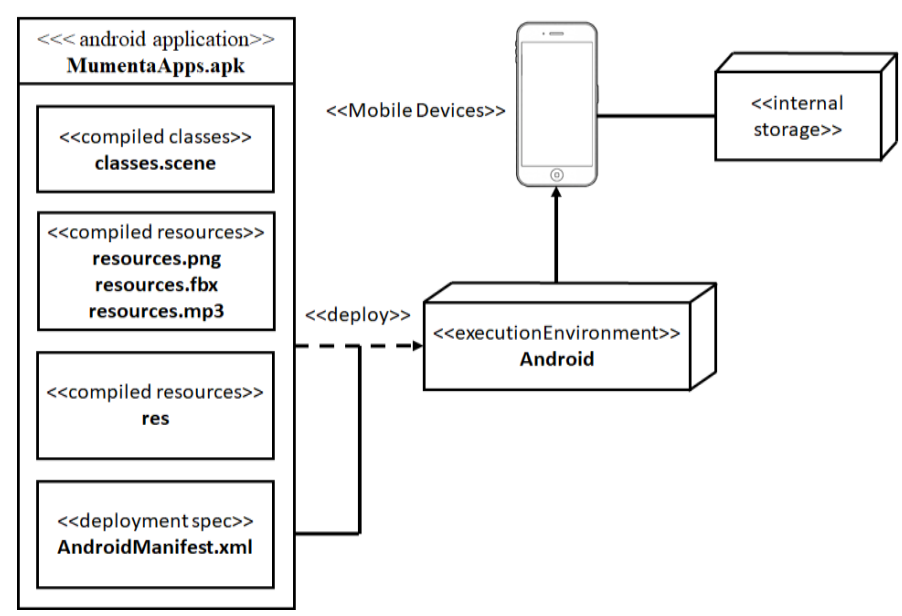

Gambar 3. 13 Deployment Diagram
Untuk lebih jelas nya maka penulis akan memberikan penjelasan singkat mengenai pengertian format-format diatas :

a. Format *apk, adalah singkatan dari Android Package, format digunakan untuk mendistribusikan aplikasi pada sistem operasi Google Android. Format ini akan penulis gunakan untuk meng kompilasi seluruh komponen.

b. Format *scene, adalah format yang ada pada unity ketika menyimpan desain proyek yang sudah dirancang sebelumnya. Format ini penulis gunakan untuk menghubungkan antar scene satu dengan scene lainnya.

c. Format *png, adalah sebuah singkatan dari portable network graphics, format ini digunakan untuk menyimpan media gambar. Format ini penulis gunakan untuk membuat design interface dan juga asset-asset tombol.

d. Format $* f b x$, adalah sebuah singkatan filmbox, format ini digunakan untuk menyimpan objek 3D museum. Format ini penulis gunakan untuk menampilkan objek museum 3D menggunakan markerless augmented reality .

e. Format *mp3, adalah sebuah singkatan dari media player 3 , format ini digunakan untuk menyimpan media musik. Format ini penulis gunakan untuk membuat suara dubbing mengenai objek museum dan suara kuis ketika pengguna menjawab kuis dengan salah atau benar.

f. *Res, adalah tempat resources yang berisi komponen-komponen untuk membuat aplikasi.

g. Format *xml, adalah sebuah singkatan dari Extensible Markup Language, kegunaan dari format ini adalah untuk memberitahukan SDK dan Type Android apa yang digunakan.

\section{Material Collecting}

Tahap ini mengumpulkan bahan bahan yang akan digunakan dalam aplikasi, seperti sketsa, data, bentuk, jenis, ukuran objek museum, dan dubbing terkait penjelasan objek museum tersebut.

3.1 Data Objek Museum \& Monumen PETA

Berikut merupakan objek-objek Museum \& Monumen PETA yang akan dijadikan Model Animasi 3D. 
Tabel 3. 2 Objek Museum \& Monumen PETA

\begin{tabular}{|c|c|c|}
\hline $\mathrm{N}$ & Objek & Deskripsi \\
\hline 1 & $\begin{array}{c}\text { Gambar } 3.14 \text { Merian } \\
\text { Gunung }\end{array}$ & $\begin{array}{l}\text { Meriam Gunung } \\
\text { adalah sebuah } \\
\text { meriam yang } \\
\text { dibuat oleh } \\
\text { Yugoslavia, } \\
\text { disebut sebagai } \\
\text { "Meriam kar } \\
\text { Gunung" karena } \\
\text { senjata ini } \\
\text { digunakan untuk } \\
\text { mempertahanka } \\
\text { n wilayah } \\
\text { pergunungan, } \\
\text { oleh karena itu } \\
\text { senjata ini di } \\
\text { desain agar } \\
\text { lebih ringan dan } \\
\text { mudah } \\
\text { dioperasikan, } \\
\text { ukuran kaliber } \\
\text { senjata ini } \\
\text { adalah } 76 m m .\end{array}$ \\
\hline 2 & $\begin{array}{c}\text { Gambar } 3.15 \text { Batu } \\
\text { Prasasti }\end{array}$ & $\begin{array}{l}\text { Batu Prasasti } \\
\text { adalah sebuah } \\
\text { batu yang } \\
\text { berada di depan } \\
\text { Museum PETA, } \\
\text { batu ini } \\
\text { bertuliskan } \\
\text { semasa } \\
\text { berkobarnya } \\
\text { perang dunia ke } \\
\text { dua di bumi } \\
\text { pembela tanah } \\
\text { air ini } \\
\text { dilahirkan, jiwa } \\
\text { keprajuritan } \\
\text { nasional } \\
\text { indonesia. Batu } \\
\text { ini dilapisi oleh } \\
\text { tembaga untuk } \\
\text { tulisannya dan } \\
\text { batu ini } \\
\text { ditemukan dari } \\
\text { sungai yang ada } \\
\text { di wilayah } \\
\text { provinsi jawa } \\
\text { tengah. }\end{array}$ \\
\hline
\end{tabular}

\begin{tabular}{|c|c|c|}
\hline 3 & $\begin{array}{c}\text { Gambar } 3.16 \\
\text { Kompas }\end{array}$ & $\begin{array}{l}\text { Kompas } \\
\text { adalah sebuah } \\
\text { benda yang } \\
\text { pernah } \\
\text { digunakan oleh } \\
\text { para pejuang } \\
\text { tanah air untuk } \\
\text { menentukan } \\
\text { arah mata angin } \\
\text { agar tidak } \\
\text { tersesat } \\
\text { diperjalanan } \\
\text { ketika hendak } \\
\text { menuju ke suatu } \\
\text { tempat. }\end{array}$ \\
\hline 4 & $\begin{array}{c}\text { Gambar } 3.17 \\
\text { Teropong }\end{array}$ & $\begin{array}{l}\text { Teropong } \\
\text { digunakan oleh } \\
\text { para pejuang } \\
\text { tanah air untuk } \\
\text { melihat } \\
\text { mengamati } \\
\text { penjajah dari } \\
\text { jarak jauh. }\end{array}$ \\
\hline 5 & $\begin{array}{c}\text { Gambar } 3.18 \text { Pis } \\
\text { Vickers }\end{array}$ & 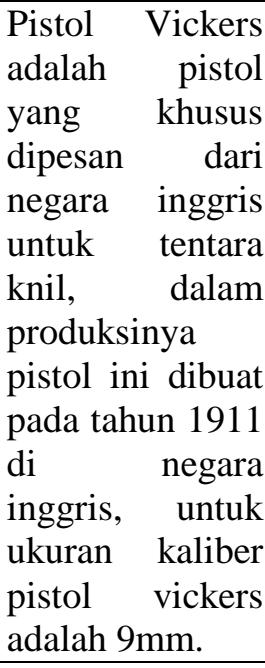 \\
\hline 6 & $\begin{array}{c}\text { Gambar } 3.19 \\
\text { Senapan Refle } 303 \\
\text { LE MK }\end{array}$ & $\begin{array}{lr}\text { Senapan } & \text { Refle } \\
303 \text { Le Mk } \\
\text { adalah sebuah } \\
\text { senapan yang } \\
\text { dibuat pada } \\
\text { tahun } 1905 \text { di } \\
\text { negara inggris. } \\
\text { Senjata ina } \\
\text { memiliki ukuran } \\
\text { kaliber sebesar } \\
7,62 m m . \\
\text { Senjata } \\
\text { digunakan oleh } \\
\text { para pembela } \\
\text { tanah air untuk }\end{array}$ \\
\hline
\end{tabular}




\begin{tabular}{|c|c|c|}
\hline & & $\begin{array}{l}\text { mengusir } \\
\text { penjajah. }\end{array}$ \\
\hline 7 & $\begin{array}{c}\text { Gambar 3.20 Pistol } \\
\text { FN }\end{array}$ & $\begin{array}{l}\text { Pistol FN adalah } \\
\text { sebuah pistol } \\
\text { yang berasal } \\
\text { dari negara } \\
\text { Kanada dengan } \\
\text { memiliki ukuran } \\
\text { kaliber 9mm, } \\
\text { pistol ini dibuat } \\
\text { pada } \\
\text { 1956. }\end{array}$ \\
\hline 8 & $\begin{array}{c}\text { Gambar } 3.21 \text { Pistol } \\
\text { Mauser }\end{array}$ & $\begin{array}{lr}\text { Pistol } & \text { Mauser } \\
\text { adalah } & \text { sebuah } \\
\text { pistol } & \text { yang } \\
\text { berasal } & \text { dari } \\
\text { negara } & \text { Jerman, } \\
\text { pistol } & \text { ini } \\
\text { memiliki } & \text { ukuran } \\
\text { kaliber } & 7,63 \mathrm{~mm} \\
\text { dan dibuat pada } \\
\text { tahun 1996. }\end{array}$ \\
\hline
\end{tabular}

3.2 Dubbing

Berikut merupakan dubbing yang sudah dibuat menggunakan botika online dan sudah dimasukan ke dalam unity 3D, adapun penjelasan detail dubbing ini adalah sebagai berikut :

Tabel 3. 3 Dubbing untuk Aplikasi

\begin{tabular}{|c|l|c|c|}
\hline No & \multicolumn{1}{|c|}{ Nama } & Durasi & Format \\
\hline 1 & suara_meriam_gunung & $\begin{array}{c}20 \\
\text { detik }\end{array}$ & $\mathrm{mp3}$ \\
\hline 2 & suara_batu_prasasti & $\begin{array}{c}25 \\
\text { detik }\end{array}$ & $\mathrm{mp3}$ \\
\hline 3 & suara_kompas & $\begin{array}{c}13 \\
\text { detik }\end{array}$ & $\mathrm{mp3}$ \\
\hline 4 & suara_teropong & $\begin{array}{c}6 \\
\text { detik }\end{array}$ & $\mathrm{mp3}$ \\
\hline 5 & suara_pistol_vickers & $\begin{array}{c}15 \\
\text { detik }\end{array}$ & $\mathrm{mp3}$ \\
\hline 6 & suara_refle_303_le_mk & $\begin{array}{c}18 \\
\text { detik }\end{array}$ & $\mathrm{mp3}$ \\
\hline 7 & suara_pistol_fn & $\begin{array}{c}20 \\
\text { detik }\end{array}$ & $\mathrm{mp3}$ \\
\hline 8 & suara_pistol_mauser & $\begin{array}{c}28 \\
\text { detik }\end{array}$ & $\mathrm{mp3}$ \\
\hline 9 & suara_jawaban_benar & $\begin{array}{c}2 \\
\text { detik }\end{array}$ & $\mathrm{mp3}$ \\
\hline 10 & Suara_jawaban_salah & $\begin{array}{c}2 \\
\text { detik }\end{array}$ & $\mathrm{mp3}$ \\
\hline
\end{tabular}

4. Assembly a. Tampilan Menu Utama

Pada bagian ini adalah bagian yang dirancang sebagai menu utama yang telah berhasil melewati Splash Screen dan Loading Screen, di menu ini terdapat beberapa button yaitu Galeri Museum, Tentang Museum, Bantuan, Profile, serta Exit.

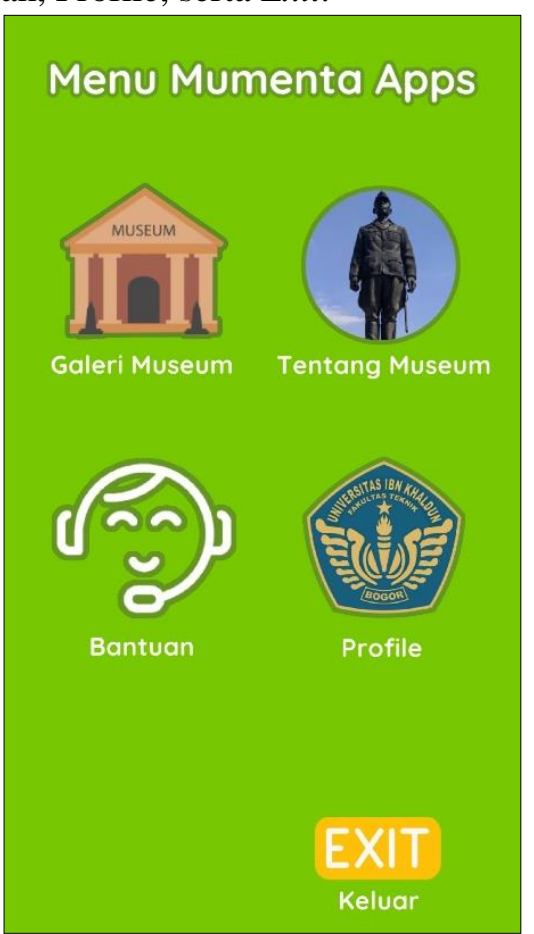

Gambar 3.22 Tampilan Menu Utama

b. Tampilan Galeri Museum

Pada bagian ini berisi objek-objek Museum \& Monumen PETA sebanyak 8 objek. 
Vol.3 No.2, Desember 2020

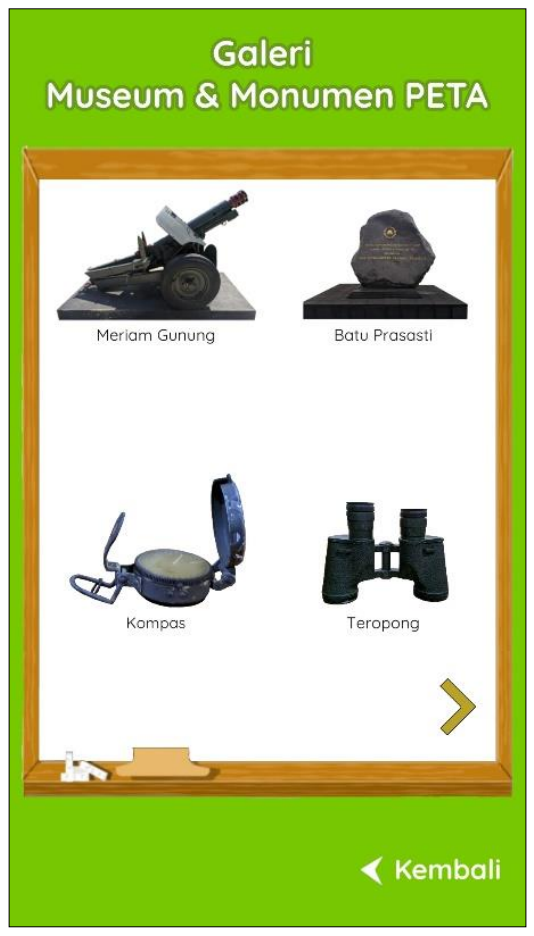

Gambar 3. 23 Tampilan Galeri Museum

c. Tampilan Detail Objek Museum

Gambar ini menunjukkan tampilan objek museum yang disertai dengan penjelasan secara teks dan juga terdapat tombol klik yang berfungsi untuk menampilkan objek dengan markerless augmented reality.

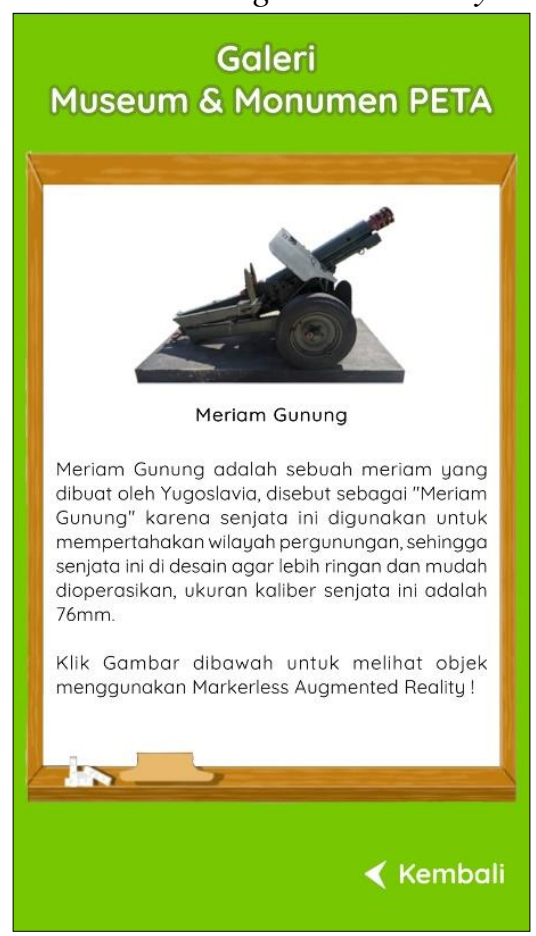

Gambar 3.24 Tampilan Detail Objek Museum d. Tampilan Objek Menggunakan Markerless Augmented Reality

Gambar ini memperlihatkan objek museum menggunakan markerless augmented reality dengan tampilan animasi 3D sehingga bisa dilihat dari segala arah dan juga terdapat suara yang menjelaskan objek tersebut.

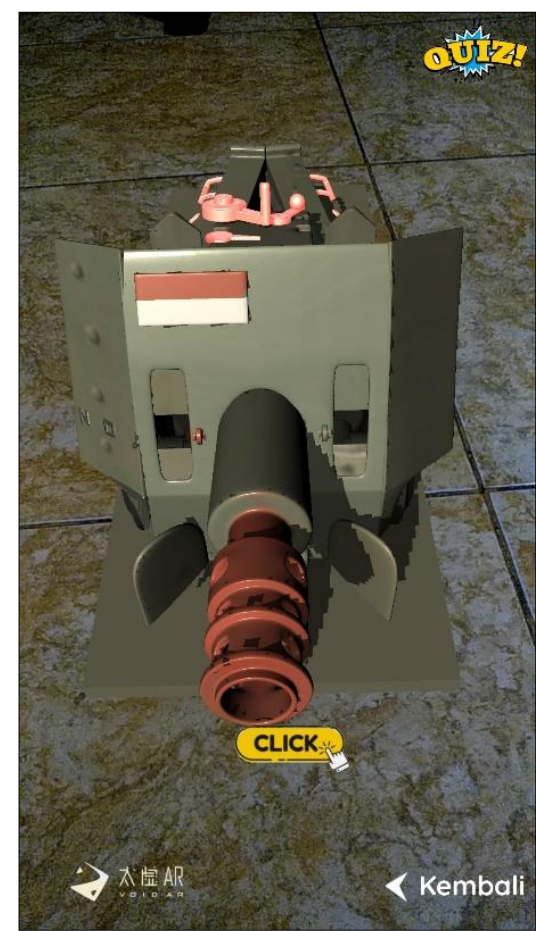

Gambar 3.25 Tampilan Objek Museum Menggunakan Markerless Augmented Reality 
e. Tampilan Kuis Objek Museum

Gambar ini memperlihatkan ada beberapa pertanyaan atau yang biasa disebut dengan kuis, pertanyaan tersebut sesuai dengan objek museum yang dipilih.

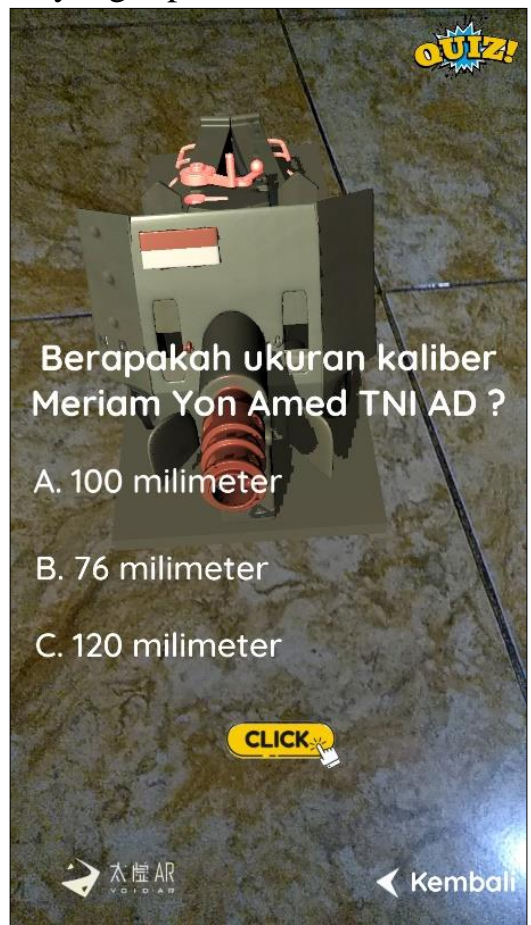

Gambar 3.26 Tampilan Kuis Objek Museum

f. Tampilan Salah Jawab Kuis

Gambar ini memperlihatkan jika pengguna menjawab pertanyaan dengan salah.

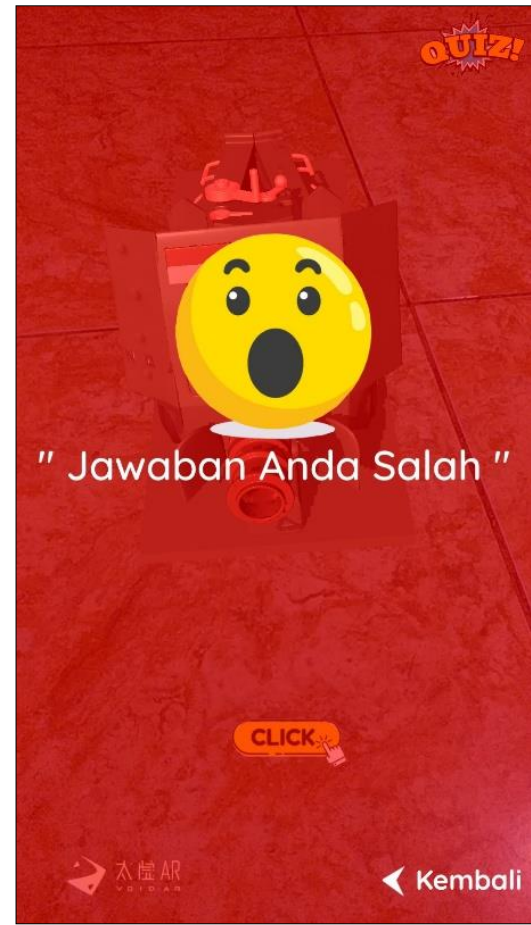

Gambar 3.27 Tampilan Salah Jawab Kuis

g. Tampilan Benar Jawab Kuis

Gambar ini memperlihatkan jika pengguna menjawab pertanyaan dengan benar.

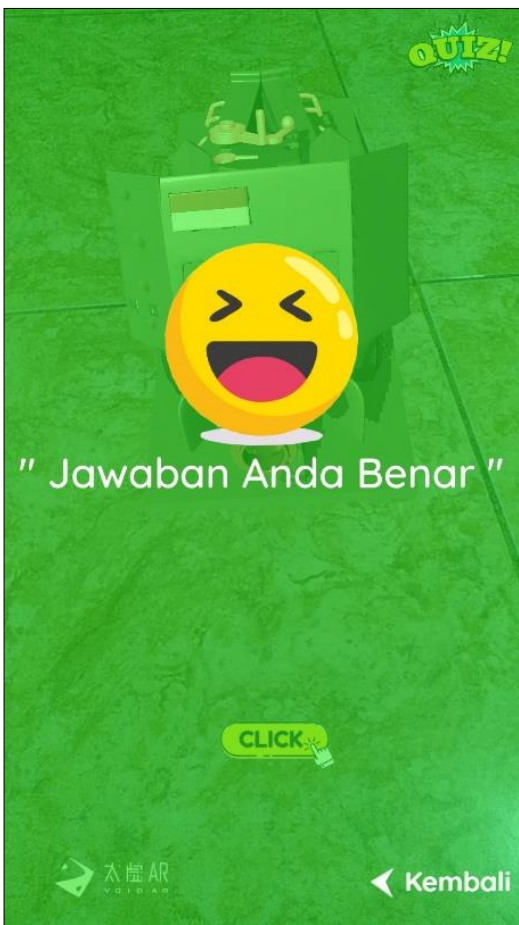

Gambar 3.28 Tampilan Benar Jawab Kuis.

5. Testing

a. Uji Coba Fungsional

Tahapan Uji Coba Fungsional ini dilakukan untuk memastikan apakah setiap 
tombol, scroll dan markerless augmented reality yang ada berjalan dengan baik. Berikut merupakan hasil koneksi tombol yang sudah berfungsi dengan baik

1. Uji Coba Tombol Aplikasi

Pada bagian ini menguji seluruh tombol yang ada di dalam aplikasi

Tabel 3. 4 Uji Coba Tombol Aplikasi

\begin{tabular}{|c|c|c|}
\hline No & Tombol & $\begin{array}{l}\text { Dijalankan di } \\
\text { Android }\end{array}$ \\
\hline 1 & $\begin{array}{l}\text { Tombol Menu } \\
\text { Galeri Museum }\end{array}$ & Berfungsi \\
\hline 2 & $\begin{array}{l}\text { Tombol Meriam } \\
\text { Gunung }\end{array}$ & Berfungsi \\
\hline 3 & $\begin{array}{l}\text { Tombol Batu } \\
\text { Prasasti }\end{array}$ & Berfungsi \\
\hline 4 & Tombol Kompas & Berfungsi \\
\hline 5 & Tombol Teropong & Berfungsi \\
\hline 6 & $\begin{array}{l}\text { Tombol Pistol } \\
\text { Vickers }\end{array}$ & Berfungsi \\
\hline 7 & $\begin{array}{l}\text { Tombol Refle } 303 \\
\text { LE MK }\end{array}$ & Berfungsi \\
\hline 8 & Tombol Pistol FN & Berfungsi \\
\hline 9 & $\begin{array}{l}\text { Tombol Pistol } \\
\text { Mauser }\end{array}$ & Berfungsi \\
\hline 10 & $\begin{array}{l}\text { Tombol Halaman } \\
\text { Selanjutnya (di } \\
\text { Menu Galeri } \\
\text { Museum) }\end{array}$ & Berfungsi \\
\hline 11 & $\begin{array}{l}\text { Tombol Halaman } \\
\text { Sebelumnya (di } \\
\text { Menu Galeri } \\
\text { Museum) }\end{array}$ & Berfungsi \\
\hline 12 & $\begin{array}{l}\text { Tombol Kembali } \\
\text { (di Galeri } \\
\text { Museum) }\end{array}$ & Berfungsi \\
\hline 13 & $\begin{array}{l}\text { Tombol Clik } \\
\text { Markerless } \\
\text { Augmented } \\
\text { Reality Meriam } \\
\text { Gunung }\end{array}$ & Berfungsi \\
\hline 14 & $\begin{array}{l}\text { Tombol Clik } \\
\text { Markerless } \\
\text { Augmented } \\
\text { Reality Batu } \\
\text { Prasasti }\end{array}$ & Berfungsi \\
\hline 15 & $\begin{array}{l}\text { Tombol Clik } \\
\text { Markerless } \\
\text { Augmented } \\
\text { Reality Kompas }\end{array}$ & Berfungsi \\
\hline 16 & $\begin{array}{l}\text { Tombol Clik } \\
\text { Markerless }\end{array}$ & Berfungsi \\
\hline
\end{tabular}

\begin{tabular}{|c|c|c|}
\hline & $\begin{array}{l}\text { Augmented } \\
\text { Reality Teropong }\end{array}$ & \\
\hline 17 & $\begin{array}{l}\text { Tombol Clik } \\
\text { Markerless } \\
\text { Augmented } \\
\text { Reality Pistol } \\
\text { Vickers } \\
\end{array}$ & Berfungsi \\
\hline 18 & $\begin{array}{l}\text { Tombol Clik } \\
\text { Markerless } \\
\text { Augmented } \\
\text { Reality Refle } 303 \\
\text { LE MK }\end{array}$ & Berfungsi \\
\hline 19 & \begin{tabular}{|l|} 
Tombol Clik \\
Markerless \\
Augmented \\
Reality Pistol FN
\end{tabular} & Berfungsi \\
\hline 20 & $\begin{array}{l}\text { Tombol Clik } \\
\text { Markerless } \\
\text { Augmented } \\
\text { Reality Pistol } \\
\text { Mauser }\end{array}$ & Berfungsi \\
\hline 21 & $\begin{array}{l}\text { Tombol Kuis } \\
\text { Meriam Gunung }\end{array}$ & Berfungsi \\
\hline 22 & $\begin{array}{l}\text { Tombol Kuis } \\
\text { Batu Prasasti }\end{array}$ & Berfungsi \\
\hline 23 & $\begin{array}{l}\text { Tombol Kuis } \\
\text { Kompas }\end{array}$ & Berfungsi \\
\hline 24 & $\begin{array}{l}\text { Tombol Kuis } \\
\text { Teropong }\end{array}$ & Berfungsi \\
\hline 25 & \begin{tabular}{|l|} 
Tombol Kuis \\
Pistol Vickers \\
\end{tabular} & Berfungsi \\
\hline 26 & \begin{tabular}{|l} 
Tombol Kuis \\
Refle 303 LE MK
\end{tabular} & Berfungsi \\
\hline 27 & $\begin{array}{l}\text { Tombol Kuis } \\
\text { Pistol FN }\end{array}$ & Berfungsi \\
\hline 28 & $\begin{array}{l}\text { Tombol Kuis } \\
\text { Pistol Mauser }\end{array}$ & Berfungsi \\
\hline 29 & $\begin{array}{l}\text { Tombol Menu } \\
\text { Tentang Museum }\end{array}$ & Berfungsi \\
\hline 30 & \begin{tabular}{|l|} 
Tombol \\
Instagram \\
\end{tabular} & Berfungsi \\
\hline 31 & \begin{tabular}{|l|} 
Tombol \\
Facebook \\
\end{tabular} & Berfungsi \\
\hline 32 & \begin{tabular}{|l|} 
Tombol \\
WhatsApp \\
\end{tabular} & Berfungsi \\
\hline 33 & $\begin{array}{l}\text { Tombol Google } \\
\text { Maps }\end{array}$ & Berfungsi \\
\hline 34 & $\begin{array}{l}\text { Tombol Kembali } \\
\text { (di Menu Tentang } \\
\text { Museum) }\end{array}$ & Berfungsi \\
\hline 35 & $\begin{array}{l}\text { Tombol Menu } \\
\text { Bantuan }\end{array}$ & Berfungsi \\
\hline 36 & Tombol Menu & Berfungsi \\
\hline
\end{tabular}




\begin{tabular}{|l|l|c|}
\hline & Profile & \\
\hline 37 & Tombol Exit & Berfungsi \\
\hline
\end{tabular}

2. Uji Coba Scroll Aplikasi

Pada bagian ini menguji seluruh Scroll yang ada di dalam aplikasi

Tabel 3. 5 Uji Coba Scroll Aplikasi

\begin{tabular}{|c|l|c|}
\hline No & \multicolumn{1}{|c|}{ Tombol } & $\begin{array}{c}\text { Dijalankan di } \\
\text { Android }\end{array}$ \\
\hline 1 & $\begin{array}{l}\text { Scroll Deskripsi } \\
\text { Meriam Gunung }\end{array}$ & Berfungsi \\
\hline 2 & $\begin{array}{l}\text { Scroll Deskripsi } \\
\text { Tombol Batu } \\
\text { Prasasti }\end{array}$ & Berfungsi \\
\hline 3 & $\begin{array}{l}\text { Scroll Deskripsi } \\
\text { Tombol Kompas }\end{array}$ & Berfungsi \\
\hline 4 & $\begin{array}{l}\text { Scroll Deskripsi } \\
\text { Tombol Teropong }\end{array}$ & Berfungsi \\
\hline 5 & $\begin{array}{l}\text { Scroll Deskripsi } \\
\text { Tombol Pistol } \\
\text { Vickers }\end{array}$ & Berfungsi \\
\hline 6 & $\begin{array}{l}\text { Scroll Deskripsi } \\
\text { Tombol Refle } 303 \\
\text { LE MK }\end{array}$ & Berfungsi \\
\hline 7 & $\begin{array}{l}\text { Scroll Deskripsi } \\
\text { Tombol Pistol FN }\end{array}$ & Berfungsi \\
\hline 8 & $\begin{array}{l}\text { Scroll Deskripsi } \\
\text { Tombol Pistol } \\
\text { Mauser }\end{array}$ & Berfungsi \\
\hline 9 & $\begin{array}{l}\text { Scroll Deskripsi } \\
\text { Tentang Museum }\end{array}$ & Berfungsi \\
\hline 10 & $\begin{array}{l}\text { Scroll Deskripsi } \\
\text { Bantuan }\end{array}$ & Berfungsi \\
\hline
\end{tabular}

3. Uji Coba Markerless Augmented Reality

Pada bagian ini menguji seluruh objek museum 3D dengan menggunakan Markerless Augmented Reality yang ada di dalam aplikasi

Tabel 3. 6 Uji Coba Markerless Augmented Reality

\begin{tabular}{|c|l|c|}
\hline No & \multicolumn{1}{|c|}{ Tombol } & $\begin{array}{c}\text { Dijalankan di } \\
\text { Android }\end{array}$ \\
\hline 1 & Objek 3D & Berfungsi \\
& Meriam Gunung & \\
& $\begin{array}{l}\text { Menggunakan } \\
\text { Markerless } \\
\text { Augmented } \\
\\
\text { Reality }\end{array}$ & \\
\hline 2 & $\begin{array}{l}\text { Objek 3D Batu } \\
\text { Prasasti }\end{array}$ & Berfungsi \\
\hline
\end{tabular}

\begin{tabular}{|c|c|c|}
\hline & $\begin{array}{l}\text { Menggunakan } \\
\text { Markerless } \\
\text { Augmented } \\
\text { Reality }\end{array}$ & \\
\hline 3 & $\begin{array}{l}\text { Objek 3D } \\
\text { Kompas } \\
\text { Menggunakan } \\
\text { Markerless } \\
\text { Augmented } \\
\text { Reality }\end{array}$ & Berfungsi \\
\hline 4 & $\begin{array}{l}\text { Objek 3D } \\
\text { Teropong } \\
\text { Menggunakan } \\
\text { Markerless } \\
\text { Augmented } \\
\text { Reality } \\
\end{array}$ & Berfungsi \\
\hline 5 & $\begin{array}{l}\text { Objek 3D Pistol } \\
\text { Vickers } \\
\text { Menggunakan } \\
\text { Markerless } \\
\text { Augmented } \\
\text { Reality }\end{array}$ & Berfungsi \\
\hline 6 & $\begin{array}{l}\text { Objek 3D Refle } \\
\text { 303 LE MK } \\
\text { Menggunakan } \\
\text { Markerless } \\
\text { Augmented } \\
\text { Reality }\end{array}$ & Berfungsi \\
\hline 7 & $\begin{array}{l}\text { Objek 3D Pistol } \\
\text { FN Menggunakan } \\
\text { Markerless } \\
\text { Augmented } \\
\text { Reality }\end{array}$ & Berfungsi \\
\hline 8 & $\begin{array}{l}\text { Objek 3D Pistol } \\
\text { Mauser } \\
\text { Menggunakan } \\
\text { Markerless } \\
\text { Augmented } \\
\text { Reality } \\
\end{array}$ & Berfungsi \\
\hline
\end{tabular}

Dalam pengujian Markerless Augmented Reality dapat diketahui bahwa dengan menggunakan SDK VOID AR objek dapat muncul dimulai dari cahaya yang redup sampai terang, namun terkadang objek sering tidak presisi dan bergerak hal ini bisa diatasi dengan menyalakan ulang smart phone yang digunakan.

\section{Uji Coba Dubbing}

Pada bagian ini menguji seluruh Dubbing (pengisi suara) yang ada di dalam aplikasi. 
Vol.3 No.2, Desember 2020

Tabel 3. 7 Uji Coba Dubbing

\begin{tabular}{|c|l|c|}
\hline No & \multicolumn{1}{|c|}{ Tombol } & $\begin{array}{c}\text { Dijalankan di } \\
\text { Android }\end{array}$ \\
\hline 1 & $\begin{array}{l}\text { Dubbing Meriam } \\
\text { Gunung }\end{array}$ & Berfungsi \\
\hline 2 & $\begin{array}{l}\text { Dubbing Batu } \\
\text { Prasasti }\end{array}$ & Berfungsi \\
\hline 3 & Dubbing Kompas & Berfungsi \\
\hline 4 & $\begin{array}{l}\text { Dubbing } \\
\text { Teropong }\end{array}$ & Berfungsi \\
\hline 5 & $\begin{array}{l}\text { Dubbing Pistol } \\
\text { Vickers }\end{array}$ & Berfungsi \\
\hline 6 & $\begin{array}{l}\text { Dubbing Refle } \\
303 \text { LE MK }\end{array}$ & Berfungsi \\
\hline 7 & $\begin{array}{l}\text { Dubbing Pistol } \\
\text { FN }\end{array}$ & Berfungsi \\
\hline 8 & $\begin{array}{l}\text { Dubbing Pistol } \\
\text { Mauser }\end{array}$ & Berfungsi \\
\hline 9 & $\begin{array}{l}\text { Dubbing Jawaban } \\
\text { Benar }\end{array}$ & Berfungsi \\
\hline 10 & $\begin{array}{l}\text { Dubbing Jawaban } \\
\text { Salah }\end{array}$ & Berfungsi \\
\hline
\end{tabular}

\section{KESIMPULAN}

Kesimpulan yang bisa ditarik setelah membuat aplikasi pengenalan objek museum peta, adalah sebagai berikut :

1. Telah membuat aplikasi pengenalan objek museum \& monumen peta menggunakan markerless augmented reality berbasis android, dan juga menggunakan objek museum 3D dalam menampilkan objek museum sehingga membantu mempermudah, menjelaskan dan memvisualisasikan objek museum kepada pengguna. Aplikasi ini bisa dijalankan kapan saja karena aplikasi ini hanya dapat dipasang diperangkat bergerak android.

\section{Saran}

Terdapat beberapa saran yang bertujuan untuk melengkapi kesimpulan, diantaranya adalah:

1. Menentukan SDK lumayan sulit karena harus mencocokan dengan perangkat yang ada

2. Kuis tanya jawab bisa dikembangkan menjadi game dengan tambahan skor atau nilai yang diperoleh jika pengguna menjawab kuis dengan benar dan ada pengurangan skor atau nilai jika pengguna menjawab kuis dengan salah.
3. Objek yang ditampilkan dapat disempurnakan lebih lanjut sehingga menghasilkan objek yang sangat realistis.

4. Menambahkan objek animasi tambahan untuk memperkaya tampilan Markerless Augmented Reality.

5. Kesulitan dalam penelitian ini adalah menentukan Source Development Kit Markerless Augmented Reality karena masing-masing SDK memiliki kelebihan dan kekurangan, penulis pun sampai berkali-kali mencoba menggunakan macam-macam SDK dimulai dari Vuforia, ARKit, ARCore hingga akhirnya penulis memilih VOID AR untuk bahan penelitian ini.

\section{REFERENSI}

Al Ikhsan, S. H., Kom, S., \& Kom, M. (2018). Implementasi Augmented Reality Labs Tour Prodi TI dengan metode Marker Based Tracking berbasis Android. INOVA-TIF, I(1).

Apriyani, M. E., Huda, M., \& Prasetyaningsih, S. (2016). Analisis Penggunaan Marker Tracking Pada Augmented Reality Huruf Hijaiyah. Jurnal Infotel, 8(1), 71-77.

Indriani, R., Sugiarto, B., \& Purwanto, A. (2016). Pembuatan Augmented Reality Tentang Pengenalan Hewan untuk Anak Usia Dini Berbasis Android Menggunakan Metode Image Tracking Vuforia. SEMNASTEKNOMEDIA ONLINE, 4(1), 4-7.

Mubarok, Z., Laxmi, G. F., \& Fajri, H. (2018). Aplikasi Game Augmented Reality Tebak Bentuk Menggunakan Fuvoria Dan Unity3d. Seminar Nasional Teknologi Informasi, 1, 814-822.

Muhammad, D., Wardhono, W. S., \& Afirianto, T. (2018). Analisis Penerapan Markerless Augmented Reality pada Video Game Memancing dengan Pendekatan Simultaneous Localization and Mapping (SLAM). Jurnal Pengembangan Teknologi Informasi dan Ilmu Komputer e-ISSN, 2548, 964X.

Prasetyo, S. A. (2014). Augmented Reality Tata Surya Sebagai Sarana Pembelajaran Interaktif Bagi Siswa Sekolah Dasar Berbasis Android. Universitas Muhammadiyah Surakarta. 
Rahadi, D. R. (2014). Pengukuran usability sistem menggunakan use questionnaire pada aplikasi android. Jurnal Sistem Informasi, 6(1).

Rahayu, F. (2019). Implementasi Augmented Reality sebagai Media Pengenalan Hewan untuk Anak Usia Dini Berbasis Android. University of Technology Yogyakarta.

Rahmadani, K., Yusmansyah, Y., \& Widiastuti, R. (2019). Hubungan Intensitas Penggunaan Smartphone dengan Interaksi Sosial Teman Sebaya. ALIBKIN (Jurnal Bimbingan Konseling), $7(5)$.

Setiadi, F. A. (2019). Rancang Bangun Aplikasi Game "Petualangan Arjuna" Berbasis Android Dengan Pemodelan Luther. Prosiding Seminar Nasional Teknologi Informasi dan Komunikasi (SENATIK), 2(1), 77-80.

Janoso, R., 2010. Application of High Performance Computing in Markerless marxentlabs.com. What is markerless Augmented Reality ? (online) dalam https://www.marxentlabs.com/what-ismarkerless-augmented-reality-deadreckoning/ (diakses pada 23 Agustus 2020 pukul. 21.00).

statcounter.com. Mobile Operating System Market Share Indonesia (online) dalam https://gs.statcounter.com/os-marketshare/mobile/indonesia (diakses pada hari Rabu 15 Juli 2020 pukul 13.44)

statista.com. Smartphone User In Indonesia (online) dalam https://www.statista.com/statistics/26672 9/smartphone-user-in-indonesia/ (diakses pada hari Rabu 15 Juli 2020 pukul 14.10)

Hadi Kusnan, 2016 Buku Panduan Monumen dan Museum PETA. Bandung : Penerbit DINAS SEJARAH ANGKATAN DARAT. 